\title{
LIMIT PERIOD BASED ON APPROXIMATE ANALYTICAL METHODS ESTIMATING INELASTIC DISPLACEMENT DEMANDS OF BUILDINGS
}

\author{
Nabil Djebbar, Nasr-Eddine Chikh \\ Dept of Civil Engineering, LMDC, University of Mentouri Constantine - Algeria \\ E-mail:djebbar-w@yahoo.fr \\ Received 8 Mar 2007; accepted 12 Oct 2007
}

\begin{abstract}
The Algerian seismic design code (RPA99) recommends a limit on the elastic period as a governing factor in the design process of low and mid-rise buildings, function of the structural system regardless of the related ductility level. The recommended limit criterion is evaluated through approximate analytical methods using drift limit. The assignable displacement ductility ratio for the force reduction factor is derived from some well established $R-\mu-T_{n}$ expressions.

The limit period evaluation procedure (proposed in this paper) agrees with a capacity design approach since it allows for adjusting the required resistance demand level function of a ductility level resulting from code's steel recommendations. This will enhance seismic design procedure based on a target-period approach such as in the Algerian seismic design code RPA99, to fulfil the minimum required two performance levels or to satisfy three performance levels if a damage control is considered. A critical study is carried out considering three regular earthquake-resistant concrete framed structures and taking into account the specificity of various types of soils, namely rock, firm and soft. A comparison of the obtained results shows clearly that the RPA99 recommended limit is only valid for nude moment resisting frames.
\end{abstract}

Keywords: earthquake resisting frames, elastic limit period, global ductility, interstorey drift, displacement, seismic design, performance level.

\section{Introduction}

Depending on the earthquake structural system, the Algerian seismic design code RPA99 [1] recommends a limit on the elastic period as a governing factor in the design process. Being a force based design code, the global behaviour factor R specified by RPA99 for a given earthquake resistant system is constant regardless of the relevant global ductility level.

The force modification factor $R_{\mu}$ is intended to be a simple tool to accomplish an inelastic design and its specified code values depend upon material of construction and the type of structural system used.

However its values seem to be arbitrary and difficult to justify since they have not been established consistently by experiment or analysis. When assessing structures to a given limit state, it is known that displacements or drifts give better indication of damage than forces [2]. In order to avoid complex nonlinear time history analysis, several simple evaluation methods have been proposed. These simplified nonlinear analysis procedures have been implemented within a well known evaluation documents such as ATC-40 [3] (based on the capacity spectrum method) and FEMA-273 [4] (based on the displacement coefficient method), in order to determine the displacement demand imposed on a building expected to deform inelastically.

Although the capacity spectrum method is simple and straightforward, the following shortcomings exist: a - iterative procedures are always needed in order to obtain the maximum structural inelastic deformation demands.

b - the ATC-40 procedure does not necessarily converge to the correct values, even if converged in many cases [5].

Recently an improved non-iterative capacity spectrum method according to the equivalent systems for estimating the maximum inelastic deformation of existing structures has been proposed [6]. A dependable single value can always be obtained. However differing from the existing capacity spectrum method, the characteristics of the equivalent system are defined by the strength ratio $\mathrm{R}$, which is obtained through the static nonlinear pushover analysis. The equivalent period of the system was derived on the secant stiffness at maximum nonlinear deformation.

It is then rational and easier to define a period limit on a deformation limit basis rather than by empirical expressions based on a general description of the structural system and its geometry.

For this reason, the global ductility level $(\mu)$ to be assigned for the force reduction factor $R_{\mu}=R / Q$ must be defined by using well established $R_{\mu}-\mu-T_{\mathrm{n}}$ relations (Newmark-Hall, Vidic-Fajfar-Fishinger, KrawinklerNasser) [5] and the earthquake response of inelastic systems can be estimated by approximate analytical methods. The evaluation of the structural limit period is conducted in order to be introduced within a performance based design procedure (Fig 1). 


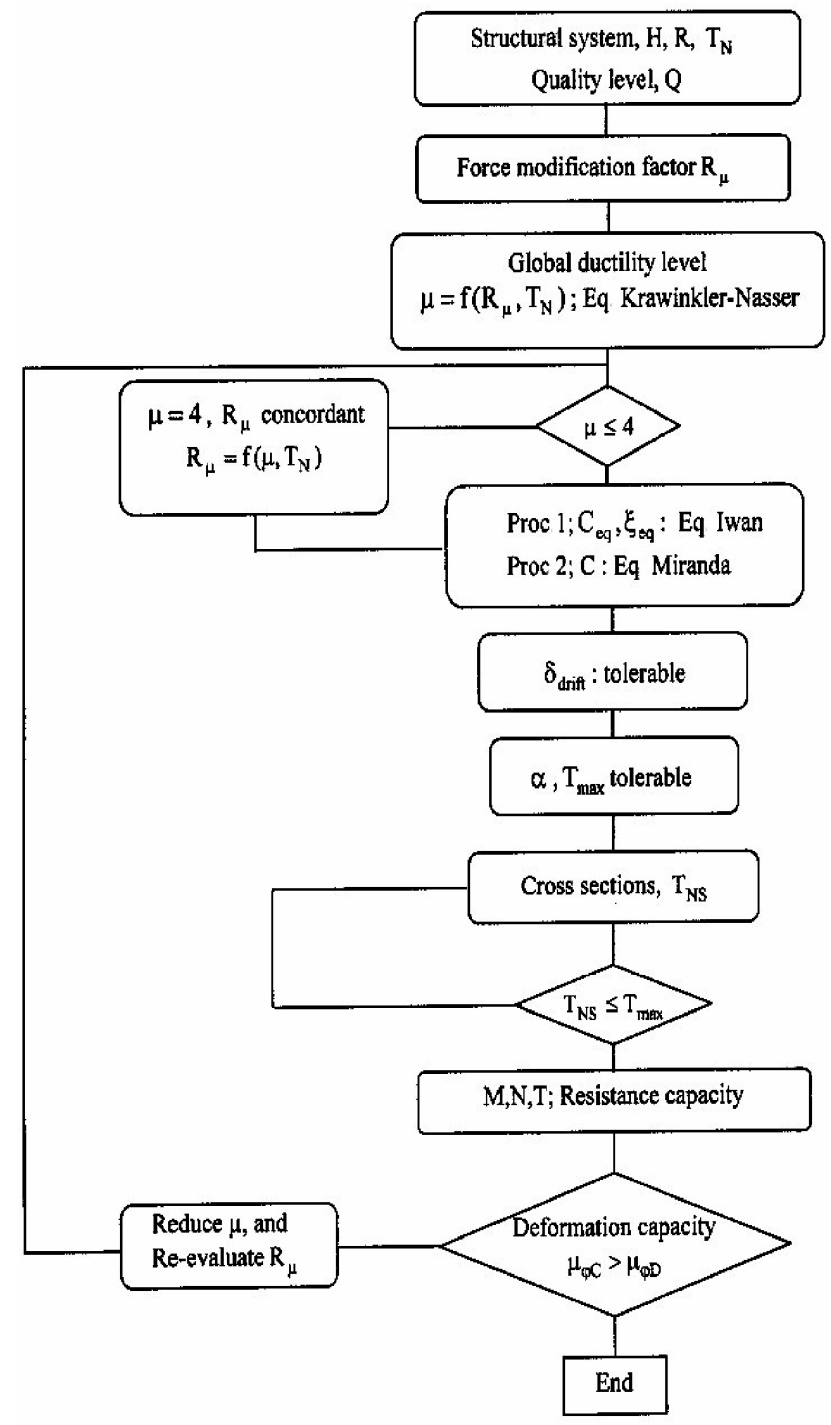

Fig 1. Design procedure for two performance level

This proportioning will guaranty a minimum lateral stiffness (maximum period $T_{\max }$ ), thus a minimum required resistance capacity to control the structural damage through a permissible deformation level or a defined ductility level. It is known that the increase in the global ductility for a given lateral rigidity or a resistance capacity has a very important effect on the local structural damage. The concentration of this damage increases with the increase of the structural ductility, in another way with the incursion degree of the structure in the nonlinear range.

Thus, the seismic response modification factor $R_{\mu}$ varies proportionally with the desired ductility level which is function of the structural period. It is also known that the damage and the ultimate rupture of an earthquake resistant structure are principally dependant on an exceedance of a deformation capacity rather than an exceedance of a resistance capacity.

It has been suggested by Chopra and Goel [7] an upper bound curve for a related height period for estimating structural assessment. However, it should be noted that the relationship has been obtained by considering just
Californian buildings, and it should be applied with caution in other parts of the world having different construction practices

Although the suggested formula provides an improved method of period estimation for structural assessment, it does not specifically take into account either the desired ductility level or the drift limit, but rather an upper bound best-fit period of vibration during "strong shaking" as defined by Chopra and Goel [8]. A simple method for proportioning regular, moderate rise RC buildings structures was proposed by Browning [9], based on target-period considering a maximum mean drift or average distortion over the height in order to reduce the expected damage. Whereas the proposed target-period formula is depending on the slope of the smoothed displacement response spectrum for a specific design ground motion.

The work undertaken herein consists in the evaluation of the period limit by assessing the maximum structural period considering a global drift by using approximate analytical methods estimating inelastic displacement demands of buildings. This will certainly contribute to the improvement of the security design level against an eventual deformation exceedance, guarantying by the way an acceptable performance level while preserving human life and limiting the damage state.

\section{Estimation of the limit period}

The evaluation of the inelastic structural response is conducted using methods based on displacement modification factor:

$$
\delta_{i}=\delta_{\text {drift }}=C . \delta_{e} \Rightarrow \delta_{e}=\frac{\delta_{d r i f t}}{C},
$$

$\delta_{i}$ represents the maximum response of the inelastic SDOF system, evaluated as the product of the maximum deformation $\delta_{e}$ of a linear system with the same lateral stiffness and the same damping coefficient as that of the inelastic SDOF system, times a displacement modifying factor, $C$.

Newmark - Hall [5] proposed different expressions for this coefficient function of the spectral region where the period of vibration of a SDOF system is localised as follows:

$$
C=\left\{\begin{array}{lc}
\mu & T_{n} \prec T_{a}=1 / 33 s, \\
\frac{\mu}{(2 \mu-1)^{\beta}} & T_{a} \leq T_{n} \prec T_{b}=0.125 s, \\
\frac{\mu}{\sqrt{2 \mu-1}} & T_{b} \leq T_{n} \prec T_{c^{\prime}}, \\
\frac{T_{c}}{T_{n}} & T_{c^{\prime}} \leq T_{n} \prec T_{c}, \\
1 & T_{n} \geq T_{c} .
\end{array}\right.
$$

with

$$
\beta=\ln \left(T_{n} / T_{a}\right) / 2 \ln \left(T_{b} / T_{a}\right)
$$


and

$$
T_{c}^{\prime}=\frac{\sqrt{2 \mu-1}}{\mu} T_{c} .
$$

Miranda [10] conducted a statistical study of ratios of maximum inelastic to maximum elastic displacements computed from ground motions recorded on firm soils. In that study Miranda concluded that, the ratio of maximum inelastic to maximum elastic displacement demands was not significantly affected by the earthquake magnitude or by the distance of the source. More recently Miranda et al [11] conducted a study on the evaluation of approximate methods to estimate maximum displacement demands, and proposed the following equation in order to compute the displacement modifying factor $C$ :

$$
C=\left[1+\left(\frac{1}{\mu}-1\right) \exp \left(-12 T \mu^{-0.8}\right)\right]^{-1} .
$$

Since $T_{\max }\left(=2 \sqrt{\delta_{e}}\right)$ is the maximum tolerable period for which the global displacement permissible criterion is satisfied, the value of the amplification coefficient of the elastic period $T_{n}$ is:

$$
\alpha=\frac{T_{\max }}{T_{n}} \quad \text { or } \quad \alpha=\frac{T_{\max }}{T_{n}}=\frac{2 \sqrt{\delta_{e}}}{T_{n}}=\frac{2}{T_{n}} \sqrt{\frac{\delta_{\text {drift }}}{C}} .
$$

\subsection{Target displacement}

Target displacement may be chosen from drift control to limit non structural damages, since limits based on drift ratio are easily converted to peak displacement. In the performance methodology, different performance levels are defined for the structure based on drift limits [12].

It has been suggested by Priestley [13] that under the development of plastic hinge yielding mechanism (beamsway), the displacement profile for severe seismic ground motions may be approximated as a linear variation.

A uniform interstorey drift angle $(\theta)$ over the height of the building $(H)$ is then achieved:

$$
\begin{gathered}
\theta=\frac{\delta_{i+1}-\delta_{i}}{h_{s}}=\frac{\delta_{\text {storey }}}{h_{s}}=\frac{\delta_{\text {roof }}}{H} \\
\Rightarrow \delta_{\text {roof }}=\theta H=\frac{\delta_{\text {storey }}}{h_{s}} H .
\end{gathered}
$$

Referring to the RPA interstorey drift limit ( $\left.\delta_{\text {storey }}=1 \% h_{\text {storey }}\right)$, the global drift will be: $\delta_{\text {roof }}=1 \% H$. For the immediate occupancy performance level, peak roof is limited to $1 \%$ of the building height. It should be noted that other values are recommended [14] for $\delta$ such as:

$\delta=1 \div 1.5 \% h_{s}$ for buildings having non-structural elements fixed in such a way that they do not interfere with structural deformation, and

$\delta=0.7 \div 0.75 \% h_{s}$ when these elements are of brittle materials (ie masonry) attached to the structure.

\section{Design procedure}

The main steps to be followed to determine the elastic period for a given structural system are:

- knowing the structural system the global behaviour factor $\mathrm{R}$ is defined;

- the factor of quality $Q$ will be fixed according to the quality control level ;

- as the factor $R_{\mu}=\frac{R}{Q}$, the assignable ductility displacement $\mu=f\left(R_{\mu}, T_{n}\right)$ is determined using

- Newmark-Hall $R_{\mu}-\mu-T_{n}$ relationship;

- the computation of the displacement modification coefficient $C=f(\mu)$ allows to obtain :

$$
\delta_{i}=\delta_{d r i f t}=C . \delta_{e} \text { thus: } \delta_{e}=\frac{\delta_{d r i f t}}{C},
$$

- knowing $T_{\max }=2 \sqrt{\delta_{e}}$, the amplification coefficient $(\alpha)$ may be evaluated as:

$$
\alpha=\frac{T_{\max }}{T_{n}} \text { or } \quad \alpha=\frac{T_{\max }}{T_{n}}=\frac{2 \sqrt{\delta_{e}}}{T_{n}}=\frac{2}{T_{n}} \sqrt{\frac{\delta_{\text {drift }}}{C}} .
$$

\section{Numerical application}

A numerical application was conducted on regular earthquake resistant concrete frames with the following type of structures:

Structure A: frames without rigid infill; $R=5.0$, $C_{T}=0.075$.

$>$ Structure B: frames with no participating rigid infill; $R=5.0, C_{T}=0.050$.

$>$ Structure $\mathrm{C}$ : frames with participating rigid infill; $R=3.5, C_{T}=0.050$.

Data: constant storey height $(h=3 \mathrm{~m})$; number of stories $n=4 \div 7 \quad$ (ie $R+3 \div R+6) ; H=h n=3 n$. According to RPA99, the elastic period is $T_{n}=C_{T} H^{\frac{3}{4}}$; the factor of quality $Q=1.2$ (since the control of the quality is not observed) and the predominant period: $T_{0}=0.3 s, 0.4 s, 0.7 s$, for rock (S1), firm (S2) and soft (S3) site respectively.

The global ductility level $\mu$ concordant with the reduction coefficient of the elastic force $R_{\mu}=R / Q$ is computed using Newmark-Hall expressions taking into account the influence of the site effect. The variation of the amplification period factor $\alpha$ is studied while varying the coefficient $C$ (Eq 2 and $\mathrm{Eq} 3$ ). Different obtained results are gathered within Table 1 .

The mean values of the coefficient $\alpha$ for the considered structural systems and nature's site are resumed in Table 2. 
Table 1. Variation of the amplification period coefficient $\alpha$, while considering site effect

\begin{tabular}{|c|c|c|c|c|c|c|c|c|c|c|c|}
\hline \multicolumn{12}{|c|}{ Rock site: S1 } \\
\hline \multicolumn{4}{|c|}{ Structural system A } & \multicolumn{4}{|c|}{ Structural system B } & \multicolumn{4}{|c|}{ Structural system C } \\
\hline \multicolumn{2}{|c|}{$\alpha_{\mathrm{NH}}$} & \multicolumn{2}{|c|}{$\alpha_{\text {Mir }}$} & \multicolumn{2}{|c|}{$\alpha_{\mathrm{NH}}$} & \multicolumn{2}{|c|}{$\alpha_{\mathrm{Mir}}$} & \multicolumn{2}{|c|}{$\alpha_{\mathrm{NH}}$} & \multicolumn{2}{|c|}{$\alpha_{\text {Mir }}$} \\
\hline$\mu$ & $\alpha$ & $\mu$ & $\alpha$ & $\mu$ & $\alpha$ & $\mu$ & $\alpha$ & $\mu$ & $\alpha$ & $\mu$ & $\alpha$ \\
\hline 4.17 & 1.432 & 4.17 & 1.345 & 4.17 & 2.152 & 4.17 & 1.820 & 2.92 & 2.152 & 2.92 & 2.010 \\
\hline 4.17 & 1.354 & 4.17 & 1.295 & 4.17 & 2.034 & 4.17 & 1.834 & 2.92 & 2.034 & 2.92 & 1.934 \\
\hline 4.17 & 1.295 & 4.17 & 1.255 & 4.17 & 1.941 & 4.17 & 1.799 & 2.92 & 1.941 & 2.92 & 1.876 \\
\hline 4.17 & 1.246 & 4.17 & 1.223 & 4.17 & 1.871 & 4.17 & 1.760 & 2.92 & 1.871 & 2.92 & 1.821 \\
\hline$\alpha_{\mathrm{s} 1}$ & 1.332 & $\alpha_{\mathrm{s} 1}$ & 1.280 & $\alpha_{\mathrm{s} 2}$ & 2.0 & $\alpha_{\mathrm{s} 2}$ & 1.803 & $\alpha_{\mathrm{s} 3}$ & 2.0 & $\alpha_{\mathrm{s} 3}$ & 1.910 \\
\hline \multicolumn{4}{|c|}{$\alpha_{\text {S1 moy }}=1.306$} & \multicolumn{4}{|c|}{$\alpha_{\mathrm{S} 2 \text { moy }}=1.902$} & \multicolumn{4}{|c|}{$\alpha_{\mathrm{S} 3 \text { moy }}=1.955$} \\
\hline \multicolumn{12}{|c|}{ Firm site: S2 } \\
\hline \multicolumn{4}{|c|}{ Structural system A } & \multicolumn{4}{|c|}{ Structural system B } & \multicolumn{4}{|c|}{ Structural system C } \\
\hline \multicolumn{2}{|c|}{$\alpha_{\mathrm{NH}}$} & \multicolumn{2}{|c|}{$\alpha_{\mathrm{Mir}}$} & \multicolumn{2}{|c|}{$\alpha_{\mathrm{NH}}$} & \multicolumn{2}{|c|}{$\alpha_{\text {Mir }}$} & \multicolumn{2}{|c|}{$\alpha_{\mathrm{NH}}$} & \multicolumn{2}{|c|}{$\alpha_{\mathrm{Mir}}$} \\
\hline$\mu$ & $\alpha$ & $\mu$ & $\alpha$ & $\mu$ & $\alpha$ & $\mu$ & $\alpha$ & $\mu$ & $\alpha$ & $\mu$ & $\alpha$ \\
\hline 4.17 & 1.432 & 4.17 & 1.345 & 5.18 & 1.935 & 5.18 & 1.820 & 3.63 & 1.935 & 3.63 & 1.944 \\
\hline 4.17 & 1.354 & 4.17 & 1.295 & 4.38 & 1.985 & 4.38 & 1.834 & 3.06 & 1.985 & 3.06 & 1.924 \\
\hline 4.17 & 1.295 & 4.17 & 1.255 & 4.17 & 1.941 & 4.17 & 1.799 & 2.92 & 1.941 & 2.92 & 1.876 \\
\hline 4.17 & 1.246 & 4.17 & 1.223 & 4.17 & 1.871 & 4.17 & 1.760 & 2.92 & 1.871 & 2.92 & 1.821 \\
\hline$\alpha_{\mathrm{s} 1}$ & 1.332 & $\alpha_{\mathrm{s} 1}$ & 1.280 & $\alpha_{\mathrm{s} 2}$ & 1.933 & $\alpha_{\mathrm{s} 2}$ & 1.803 & $\alpha_{\mathrm{s} 3}$ & 1.933 & $\alpha_{\mathrm{s} 3}$ & 1.890 \\
\hline \multicolumn{4}{|c|}{$\alpha_{\text {S1 moy }}=1.306$} & \multicolumn{4}{|c|}{$\alpha_{\mathrm{S} 2 \text { moy }}=1.868$} & \multicolumn{4}{|c|}{$\alpha_{\mathrm{S} 3 \text { moy }}=1.912$} \\
\hline \multicolumn{12}{|c|}{ Soft site: $\mathrm{S} 3$} \\
\hline \multicolumn{4}{|c|}{ Structural system A } & & tructure & ystem 1 & & & Structura & ystem & \\
\hline & & & & & & & & & & & \\
\hline$\mu$ & $\alpha$ & $\mu$ & $\alpha$ & $\mu$ & $\alpha$ & $\mu$ & $\alpha$ & $\mu$ & $\alpha$ & $\mu$ & $\alpha$ \\
\hline 6.03 & 1.190 & 6.03 & 1.272 & 9.0 & 1.460 & 9.0 & 1.583 & 4.76 & 1.700 & 4.76 & 1.853 \\
\hline 5.10 & 1.224 & 5.10 & 1.267 & 7.66 & 1.503 & 7.66 & 1.635 & 4.76 & 1.592 & 4.76 & 1.804 \\
\hline 4.46 & 1.253 & 4.46 & 1.248 & 6.68 & 1.534 & 6.68 & 1.659 & 4.68 & 1.534 & 4.68 & 1.769 \\
\hline 4.17 & 1.246 & 4.17 & 1.217 & 5.96 & 1.565 & 5.96 & 1.670 & 4.17 & 1.565 & 4.17 & 1.765 \\
\hline$\alpha_{\mathrm{s} 1}$ & 1.228 & $\alpha_{\mathrm{s} 1}$ & 1.251 & $\alpha_{\mathrm{s} 2}$ & 1.515 & $\alpha_{\mathrm{s} 2}$ & 1.637 & $\alpha_{\mathrm{s} 3}$ & 1.594 & $\alpha_{\mathrm{s} 3}$ & 1.798 \\
\hline & $\alpha_{\text {S1 moy }}$ & 1.240 & & & $\alpha_{\mathrm{S} 2 \mathrm{moy}}$ & 1.576 & & & $\alpha_{\text {S3 moy }}$ & 1.696 & \\
\hline
\end{tabular}

Table 2. Mean values of the amplification period coefficient $\alpha$, considering site effect

\begin{tabular}{c|c|c|c|c}
\hline \multirow{2}{*}{ Structural system } & \multicolumn{4}{|c}{ Nature of the site } \\
\cline { 3 - 6 } & $\mathrm{S} 1$ & $\mathrm{~S} 2$ & $\mathrm{~S} 3$ & $\alpha=\frac{\alpha \mathrm{s} 1+\alpha \mathrm{s} 2+\alpha \mathrm{s} 3}{3}$ \\
\hline $\mathrm{A}: \mathrm{R}=5 ; \quad \mathrm{C}_{\mathrm{T}}=0.075$ & 1.306 & 1.306 & 1.240 & 1.284 \\
\hline $\mathrm{B}: \mathrm{R}=5 ; \quad \mathrm{C}_{\mathrm{T}}=0.050$ & 1.902 & 1.868 & 1.576 & 1.782 \\
\hline $\mathrm{C}: \mathrm{R}=3.5 ; \quad \mathrm{C}_{\mathrm{T}}=0.050$ & 1.955 & 1.912 & 1.696 & 1.854 \\
\hline
\end{tabular}

Table 3. Mean values of the amplification coefficient $\alpha$, while considering $(\mathrm{HN})$ and not considering site effect (Kw - Nasser).

\begin{tabular}{|c|c|c|c|}
\hline Structural system & $\alpha_{1}=\mathrm{NH}$ & $\alpha_{2}=\mathrm{Kw}-$ Nasser & $\frac{\alpha_{2}-\alpha_{1}}{\alpha_{2}}(\%)$ \\
\hline A. $\mathrm{R}=5 ; \mathrm{C}_{\mathrm{T}}=0.075$ & 1.284 & 1.271 & 1.02 \\
\hline B. $\mathrm{R}=5 ; \mathrm{C}_{\mathrm{T}}=0.050$ & 1.782 & 1.745 & 2.12 \\
\hline C. $\mathrm{R}=3.5 ; \mathrm{C}_{\mathrm{T}}=0.050$ & 1.854 & 1.873 & 1.01 \\
\hline & & Mean error & $1.38 \%$ \\
\hline
\end{tabular}


Examining the results contained in the previous table, it can be noticed that the site effect does not have a great influence on the variation of $\alpha$.

The same procedure is followed using the coefficient C proposed by Miranda and the Krawinkler-Nasser $R_{\mu}-\mu-$ $T_{n}$ expression [5], in which the site condition parameter is not included though it has been established on the basis of alluvium and rock site records. However, the influence of the governing parameters such as yield level and hardening coefficient was taken into account, assuming a $5 \%$ damping value. For a hardening parameter of the hysteretic model $\alpha=0$ (elastoplastic model), the regression constants are $a=1$ and $b=0.42$.

The results gathered in Table 3 show that the influence of the used $R_{\mu}-\mu-T_{n}$ expressions on the period amplification coefficient is negligible.

A similar work [15] was previously conducted using another procedure where the limit criteria is evaluated through a technique based on an equivalent linearization method in which the maximum deformation (global drift) is estimated as the maximum deformation of a linear elastic system with lower stiffness and with higher damping coefficient than those of inelastic system. The significance of the approximate linearisation method incorporating the effective damping model has been introduced by Iwan and Gates [16].

In assessing the accuracy of damping models used in displacement seismic demand evaluation and design of inelastic structures, Xue [17] concluded that structures with ductility ratio $\mu_{\Delta} \leq 4$, the damping model presented by Iwan and Gates gives the most accurate results. However for $\mu_{\Delta} \succ 4$, Kowalsky's model based on the laboratory test results and curve fitting [18] is the most suitable.

The main steps of this design procedure to be followed to determine the elastic period for a given structural system are:

- knowing the structural system the global behaviour factor $\mathrm{R}$ is defined;

- the factor of quality $\mathrm{Q}$ will be fixed according to the quality control level;

- as the factor $R_{\mu}=\frac{R}{Q}$, the assignable ductility displacement $\mu=f\left(R_{\mu}, T_{n}\right)$ is determined using $R_{\mu}-\mu-T_{n}$ relation from Newmark-Hall, Vidic-Fajfar- Fishinger, Krawinkler-Nasser;

- the characteristics of the equivalent system are evaluated as follows:

$-C_{e q}=f(\mu)$

$$
C_{e q}=\frac{T_{e q}}{T}=1+0.121(\mu-1)^{0.939}
$$

$-\xi_{e q}=f(\mu)$ is obtained considering 2 cases:

Iwan [16]:

$$
-\mu_{\Delta} \leq 4 ; \quad \xi_{\text {eff }}=0.05+0.0587(\mu-1)^{0.371}
$$

Kowalsky [18]:

$$
-\mu_{\Delta} \succ 4 ; \quad \xi_{\text {eff }}=0.05+0.39372\left[1-\frac{1}{\sqrt{\mu}}\right] \text {. }
$$

Since the design process is conducted according to a $5 \%$ damped spectrum, the peak displacement must be adjusted to allow for the effective damping ratio $\xi_{e q}$, $\delta_{e q}=f\left(\delta_{\text {presumed }}, \xi_{e q}\right)$.

To convert spectral displacement from $5 \%$ level to effective damping values, the EC8 [19] recommends the following expression: $\eta=\sqrt{\frac{7}{2+\xi_{e q}}}$.

The equivalent global displacement will be then $\delta_{e q}=\frac{\delta_{\text {presumed }}}{\eta}$, leading to an equivalent elastic period $T_{e q}=2 \sqrt{\delta_{e q}}$

- The maximum estimation of the system's period $T_{\max }$ is fixed, after the determination of the equivalent elastic system characteristics, namely $\xi_{e q}, C_{e q}$, and the maximum allowable global displacement.

As the equivalent system has a unique period of vibration, thus $T_{e q}=C_{e q} \cdot T_{\max }=2 \sqrt{\delta_{e q}}$, where $T_{\max }$ in this stage represents the maximum elastic period corresponding to the imposed global displacement, which must be different from the elastic period given by the code equations.

$$
T_{\max }=\frac{T_{e q}}{C_{e q}}
$$

the amplification coefficient for the elastic period $T_{n}$ will be then:

$$
\alpha=\frac{T_{\max }}{T_{n}}=\frac{2 \sqrt{\delta_{e q}}}{C_{e q} \cdot T_{n}}=\frac{2 \sqrt{\frac{\delta_{\text {presumed }}}{\eta}}}{C_{e q} \cdot T_{n}} .
$$

Most of the structures addressed by the Algerian code are mainly short or mid-rise buildings and its recommendations for steel reinforcement [20] are in accordance with the medium ductility class (M) defined by the EC8.

This specifity is taken into account by adapting the investigation to a level of ductility $\mu \leq 4$, in order to adjust, if necessary, the concordant $R_{\mu}$.

This allows to bypass the regulation's lack concerning the deformation control routine, giving thereby the possibility to ensure the required security level by adopting the recommended RPA99 steel ratios and to adjust the required resistance demand level.

Tables 4 and 5 gather the different values obtained for the period amplification coefficient $\alpha$ by the 2 procedures for the 3 considered type of structures, taking into account or not the site effect. 
Table 4. Period amplification coefficient $\alpha$ considering site effect

\begin{tabular}{c|c|c|c|c|c|c|c|c}
\hline \multirow{2}{*}{$\begin{array}{c}\text { Structural } \\
\text { system }\end{array}$} & \multicolumn{4}{|c|}{ General } & \multicolumn{4}{c}{ Adjusted to RPA99 steel ratios } \\
\cline { 2 - 10 } & Proc 1 & Proc 2 & Error & Mean & Proc 1 & Proc 2 & Error & Mean \\
\hline A & 1.310 & 1.285 & 1.98 & 1.298 & 1.310 & 1.285 & 1.98 & 1.298 \\
\hline B & 1.931 & 1.782 & 7.72 & 1.857 & 1.830 & 1.836 & 0.33 & 1.833 \\
\hline C & 1.980 & 1.853 & 6.36 & 1.918 & 1.980 & 1.857 & 6.36 & 1.918 \\
\hline
\end{tabular}

Table 5. Period amplification coefficient $\alpha$ without considering site effect

\begin{tabular}{c|c|c|c|c|c|c|c|c}
\hline \multirow{2}{*}{$\begin{array}{c}\text { Structural } \\
\text { system }\end{array}$} & \multicolumn{4}{|c|}{ General } & \multicolumn{4}{c}{ Adjusted to RPA99 steel ratios } \\
\cline { 2 - 10 } & Proc 1 & Proc 2 & Error & Mean & Proc 1 & Proc 2 & Error & Mean \\
\hline A & 1.356 & 1.271 & 6.27 & 1.313 & 1.356 & 1.271 & 6.27 & 1.313 \\
\hline B & 1.929 & 1.745 & 9.53 & 1.837 & 1.830 & 1.836 & 0.33 & 1.833 \\
\hline C & 2.022 & 1.873 & 7.37 & 1.948 & 2.022 & 1.873 & 7.37 & 1.948 \\
\hline
\end{tabular}

Procedures 1 and 2 refer to the used approximate methods, respectively the equivalent linearisation method and the method based on the displacement modification coefficient $\mathrm{C}$. The results produced by both approaches are very close, with those given by procedure 1 slightly in excess.

By examining the mean values obtained for the amplification coefficient $\alpha$ by the two procedures, the following practical expressions to evaluate $T_{\max }$ may be

recommended for $\delta=1.0 \% h_{s}$ :

Structure A: frames without rigid infill; $T_{\max }=1.30 T_{n}$.

$>$ Structure B: frames with no participating rigid infill; $T_{\max }=1.80 T_{n}$.

$>$ Structure $\mathrm{C}$ : frames with participating rigid infill; $T_{\text {max }}=1.90 T_{n}$.

However, it is more reasonable to reduce the interstorey drift when a structure with participating rigid infill is considered in order to limit the non-structural damage. When the interstorey is $\delta=0.7 \% h_{s}, T_{\max }$ will be then: $T_{\max }=1.9 T_{n} \sqrt{0.7}=1.60 T_{n}$.

\section{Conclusions}

The evaluation procedure proposed in this work may serve as a means to control the global behaviour, guaranteing a minimum resistance capacity agreeing with the permissible deformation level necessary for controlling the structural damage. The possibility to adjust the performance levels is introduced as a way of flexibility allowing the designer to take precaution first against an eventual exceedance of deformation capacity. This alternative will surely contribute to improve the design security level while limiting the resulting damage.
The critical study is carried out considering 3 regular earthquake-resistant concrete framed structures and taking into account the specificity of various types of soils; namely rock, firm and soft. A comparison of the obtained results shows clearly that the RPA99 recommended limit is only valid for nude moment resisting frames. However, with regards to structures with rigid masonry infill, this limit is found not appropriate for a performing seismic design.

\section{References}

1. RPA99 Règles Parasismiques Algériennes, CGS, Algiers, Jan 2000.

2. PRIESTLEY, M. J. N. Displacement-based seismic assessment of reinforced concrete buildings. Journal of Earthquake Engineering, 1997, 1(1), p. 157-192.

3. ATC-40. Seismic evaluation and retrofit of concrete buildings. Applied Technology Council. California, 1996.

4. FEMA-273: NEHRP. Guidelines for seismic for the seismic rehabilitation of buildings. Federal Emergency Management Agency, Washington, D C, 1997.

5. CHOPRA, A. K.; GOEL, R. K. Capacity-demanddiagram methods based on inelastic for estimating seismic deformation of inelastic structures: SDF systems. Report No PEER-1999/02, Pacific Earthquake Engineering Research Center. University of California, Berkeley, California. Available from Internet: <http://peer.berkeley. edu/publications/peer_reports/reports_1999>.

6. LIN, Y.; MIRANDA, E. Non-iterative capacity spectrum method based on equivalent linearization for estimating inelastic deformation demands of buildings. Structural Engineering /Earthquake Engineering, 2004, 21(2), p. 113-119.

7. CHOPRA, A. K.; GOEL, R. K. Building period formulas for estimating seismic displacements. Earthquake Spectra, 2000, 16(2), p. 533-536.

8. CHOPRA, A. K.; GOEL, R. K. Period formulas for moment-resisting frame buildings. Journal of Structural Engineering, 1997, 123(11), p. 1454-1461. 
9. BROWNING, J. P. Proportioning of earthquake-resistant RC building structures. Journal of Structural Engineering, 2001, 127(2), p. 145-151.

10. MIRANDA, E. Inelastic displacement ratios for structures on firm soils. Journal of Structural Engineering, 2000, 126(10), p. 1150-1159.

11. MIRANDA, E.; RUIZ-GARCIA, J. Evaluation of approximate methods to estimate maximum inelastic displacement demands. Earthquake Engineering and Structural Dynamics, 2002, 31(3), p. 539-560.

12. SEAOC. Vision 2000. Performance based seismic engineering buildings, Vols. I and II: Conceptual framework. Structural Engineers Association of California, 1995.

13. PINHO, R.; GLAISTER, S. M. Development of a simplified deformation-based method for seismic vulnerability assessment. Journal of Earthquake Engineering, 2003, 7 (special issue 1), p. 107-140.

14. PENELIS, G. G.; KAPPOS, A. J. Earthquake-resistant concrete structures. New York: E\& FN Spon, 1997.

15. DJEBBAR, N.; CHIKH, N. A critical study of the elastic period as recommended by the RPA99 code. In 8th Inter- national Conference, Al-Azhar AEIC04, Dec. 24-27, 2004.

16. IWAN, W. D.; GATES, N. C. The effective period and damping of a class of hysteretic structures. Earthquake and Structural Dynamics, 1979, 7(3), p. 199-212.

17. XUE, Q. Assessing the accuracy of the damping models used in displacement based seismic demand evaluation and design of inelastic structures. Earthquake Engineering and Engineering Seismology, 2003, 3(2), p. 37-45.

18. PRIESTLEY, M. J. N and KOWALSKY, M. J. Direct displacement-based seismic design of concrete buildings. Bulletin of the New Zealand Society of Earthquake Engineering, 2000, 33(4), p. 421-444.

19. EN 1998-1. Eurocode 8. Design of structures for earthquake resistance. Part 1: General rules, actions and rules for buildings, Comité Européen de Normalisation, Brussels, Belgium, 2004. 222 p.

20. DJEBBAR, N.; BOUSALEM, B.; CHIKH, N. Notions of global-local behaviour in the seismic performance of concrete frames. Revue Sciences \& Technologie, 2003, 20, p. 63-69 (in French).

\section{RIBINĖS ZONOS RADIMAS, TAIKANT APROKSIMACINIUS ANALITINIUS METODUS BEI IৃERTINANT PASTATŲ NETAMPRIŲJŲ POSLINKIŲ POREIKI}

\section{N. Djebbar, N. Chikh}

Santrauka

Projektuojant žemus ir vidutinio aukščio pastatus pagal Alžyro seisminio projektavimo normas (RPA99) rekomenduojama ribinę tamprumo zonos reikšmę taikyti kaip pagrindini veiksni bei ịvertinti konstrukcinès sistemos funkcija, nekreipiant dėmesio ị esamą plastiškumo lygị. Rekomenduojamas ribinis kriterijus apskaičiuojamas, taikant aproksimacinius analitinius metodus bei tampriojo poveiksmio ribinę reikšmę. Mažinant jẻgos koeficientą poslinkiu plastiškumo santykis imamas, taikant gerai žinomas $R-\mu-T_{n}$ priklausomybes. Pasiūlyta ribinès zonos nustatymo procedūra lengvai dera prie laikomosios galios apskaičiavimo, kadangi atsparumo poreikio funkcijoje îvertinamas reikalingas plastiškumo lygis. Atsparumo poreikio funkcija randama remiantis metalinių konstrukcijų projektavimo normomis. Šis būdas leidžia pagerinti seisminio projektavimo metodus, aprašytus RPA99, kai konstrukcijos skaičiuojamos dviem darbo aspektais arba trimis, îvertinant suirties atsparị. Pasiūlytas metodas pritaikytas skaičiuojant tris žemès drebejjimams atsparius betoninius rèmus esant trims pagrindo tipams: uolai, kietajam ir minkštajam gruntams. Gautų rezultatu palyginimas leidžia daryti išvadą, kad pagal RPA99 nustatyta ribinè reikšmė galioja tiktai rẻmams, suprojektuotiems pagal lenkimo momentus.

Reikšminiai žodžiai: žemės drebėjimams atsparūs rẻmai, ribinẻ tamprumo zona, globalusis plastiškumas, tarpaukštinis dreifas, seisminis projektavimas.

Nabil DJEBBAR. Associate Professor at the University of Constantine, Algeria. His research interests include: design and retrofit of earthquake-resistant RC structures.

Nasr-Eddine CHIKH. Professor at the University of Constantine, Algeria. His research interest include: behaviour of earthquake-resistant RC structures, strengthening the concrete elements with FRP materials. 